\title{
Consumers' Perception Towards Green Products in Nepal
}

\author{
Gopal Thapa, Ph.D. \\ Associate Professor \\ Nepal Commerce Campus, Faculty of Management, T.U.
}

\begin{abstract}
The concept of green products is not very old in Nepal. This research paper is an endeavor to examine consumer level of awareness and perception towards green products in Nepal. The data has been collected from a total of 192 respondents in Kathmandu through well-structured questionnaire. An increasing number of consumers have adequate knowledge about green products features, majority of them view green products as healthy and safe. Consumers prefer to believe that green products are offering high quality over conventional products, but they are not having any precise opinion about the excessive prices of green products. The research results also find out consumers' disappointment towards the promotional measures taken by the marketer. This research will be a good cognizance for the marketers and will increase their seriousness to focus more on making consumer more aware about green products benefits and bring about the adoption of green products.

Keywords: Global Warming, Green movement, Green Product, Conventional Product, Promotional Strategies
\end{abstract}

\section{Introduction}

The marketing of "environmentally friendly" products is considered as green marketing (Thapa 2008). The American Marketing Association defines green marketing as the marketing of the products that ensures environmental safety and all the efforts taken by a firm for the purpose of production, promotion, packaging, products modification and introduction of new technologies are required to be responsive to ecological concerns. Green marketing is the exchange process of satisfying human needs and wants in which all included activities must be designed with minimum harmful impact on the natural environment with an intention to satisfy these needs (Polonsky, 1994).

\section{Literature Review}

The holistic view of green marketing intended that environmental friendly strategies must be adopted by the marketers by considering the entire chain of the events that the company enlists in because of the nature of environmental issues (Hess and Timen, 2008).Consumers' growing concern for environment and their own protection drives the demand for green products which motivates to improve the environmental performances of many companies. Consumers are the key who can drive the green marketing process (Sudir Sachdev, 2011).

Consumers are not extremely bound to environment and they put too much responsibility on industry and government (Maheshwari and Malhotra, 2011) Tan Booi Chen and Lau Teck (2010) pinpointed that consumer favorable attitudes towards the environmental protection didn't accelerate consumer attitudes on green products. It can be contrasted from the study conducted by Rouf Ahmad and Dr. Rajendran (2014). 
They investigated that consumer buying behavior could be altered with the level of consumer awareness, but marketer and marketing should focus on educating the consumers' about to how green products are more beneficial to them.

The realization of the consumers about their roles and responsibilities towards environmental protection is gradually changing and companies are looking forward to making more environmentally friendly products, lessening the wasted materials and performing more organized operation. (Jacob, Jolly, 2012). On the other hand, E.B. Khedkar (2015) pointed out that consumer think companies should act in accordance with the environmental laws set by the country, but marketers' activities and advertisement were not act as influential factors to the decision regarding the purchase of green products.

Health consciousness preceded environmental concerns are the leading factors that motivate consumers to purchase green products. Consumer's desire for organic food for the safety of health and environment influences their temptations towards organic foods.(C.Gan, G. Zhiyou and M.C. Tran ,2014). Customer's loyalty followed by global warming, products quality, price luxury and environmental awareness are regarded as the important influential factors in making green products purchase decision (Jesmin 2012).

A survey executed by Chang and Fong (2010) on consumers who were experienced in purchasing green products had identified that there is a positive association between green product quality with consumer satisfaction and consumer loyalty. They also explored that green corporate image can lead green consumer loyalty and consumer satisfaction. Sanjeev, Radha and Anita (2012) assessed consumer awareness and perception towards green products on Indian youngsters and found that respondents who demanded to be informed about green products actually don't know as to what green products literally represent. Even they can't differentiate between green and non-green products. Gan, Wee, Zucie (2008) showed that there is a positive relationship between environmental consciousness and consumer purchase decision but brand consciousness negatively influences consumer's green products buying decision. They also found in their study that higher price and unfamiliar brand decrease the likelihood to purchase the green products.Patra and Dhani (2011) scrutinized that most of the consumers are aware of green marketing and they are ready to buy green products and willing to pay extra money for sustainable environment but the marketer should give more emphasize on consumer's personal benefits and make green products more economical compare to non green products.

Insufficient information about green products is the major reason that acts as a discouragement for the non purchaser in purchasing green products (C.Gan, G. Zhiyou and M.C. Tran ,2014). Almost identical result was found in the study of Jacob and Jolly (2012). In their research, they observed that insufficient communication is a major reason for commercial breakdown. Proper communication is a significant movement to create positive behaviors among customers. A study conducted by Jesmin (2012) on Bangladeshi consumers identified that, male respondents are more acquainted with holding favorable attitudes towards green marketing than that of female.

A study conducted by Johir Ishak and Tajimul (2014) on Bangladeshi consumers discovered that current distribution channel used by the marketers' to make green products available to consumer is disappointing and insufficient. They also proved that existing distribution channel and environmental awareness have a negative relationship.

So it is observed from the above discussion that many studies have been conducted on consumer perception towards green products. However, to the best knowledge of the researchers no comprehensive study has so far been conducted to explore and assess consumer awareness and purchase attitude towards green products. So the study in hand is an exploratory research on the above mentioned area.

\section{Objectives of the study}

i. To know consumer's knowledge about various features of green product.

ii. To analyze consumer's intuitive understanding about the price of green product.

iii. To figure out if there is any misconception among consumers regarding the attributes of green product.

iv. To know customer's attitude towards the promotional strategies of green product. 


\section{Research Methodology}

The present study is a primary data based exploratory study. The data has been gathered using a wellstructured questionnaire. The questionnaire has been developed by getting ideas from various literatures related to this study. The data has been collected from the individual who have heard about the term green product. The sampling technique used for this study was convenience sampling, since it was difficult to reach the population. Likert scale placing from 1 to 5 has been subsumed in this research, where, ' 1 ' means strongly disagree and ' 5 ' means strongly agree, to analyze consumers' perception towards green products. The survey was conducted on 192 respondents of different ages in Kathmandu city who met the objectives of the research. Both descriptive (frequency, percentage, mean, standard deviation) and inferential analysis (ANOVA) techniques have been used for the analyzing the data.

\section{Results and Discussion}

It is obvious to know respondents' socio-economic profile for analyzing consumer awareness and purchase attitude towards green product because different socio-economic factors may have significant impact on consumer purchase attitude. Table 5.1 is a reflection of demographic profile of the respondents.

Table 1: Demographic information of the respondents

\begin{tabular}{|c|c|c|c|c|c|}
\hline Variables & Categories & $\begin{array}{c}\text { Percentage of } \\
\text { respondents }\end{array}$ & Variable & Categories & $\begin{array}{c}\text { Percentage of } \\
\text { respondents }\end{array}$ \\
\hline \multirow[t]{2}{*}{ Gender } & \multirow{2}{*}{$\begin{array}{l}\text { Male } \\
\text { Female }\end{array}$} & 75.0 & \multirow[t]{6}{*}{ Income } & \multirow{6}{*}{$\begin{array}{l}\text { Below or Equal Rs. } 10000 \\
\text { Rs. } 10001-25000 \\
\text { Rs. } 25001-40000 \\
\text { Rs. } 40001-55000 \\
\text { Rs. 55001-70000 } \\
\text { Above Rs.70000 }\end{array}$} & 12.0 \\
\hline & & 25.0 & & & 28.6 \\
\hline \multirow[t]{5}{*}{ Age } & \multirow{5}{*}{$\begin{array}{l}<18 \\
19-25 \\
26-35 \\
36-45 \\
>45\end{array}$} & 1.6 & & & 28.1 \\
\hline & & 34.9 & & & 15.6 \\
\hline & & 39.6 & & & 10.9 \\
\hline & & 14.1 & & & 4.7 \\
\hline & & 9.9 & \multirow[t]{6}{*}{ Occupation } & \multirow{5}{*}{$\begin{array}{l}\text { Student } \\
\text { Business man } \\
\text { Government service holder } \\
\text { Private service holder } \\
\text { Unemployed }\end{array}$} & 16.1 \\
\hline \multirow[t]{5}{*}{ Education } & \multirow{4}{*}{$\begin{array}{l}\text { Primary or below } \\
\text { Secondary } \\
\text { Graduation } \\
\text { Post Graduation and } \\
\text { Above }\end{array}$} & 1.6 & & & 18.8 \\
\hline & & 30.2 & & & 6.3 \\
\hline & & 39.1 & & & 41.7 \\
\hline & & 29.2 & & & 2.1 \\
\hline & & & & & 15.1 \\
\hline
\end{tabular}

It is observed that, $75 \%$ were male and the rest $25 \%$ were female. In this table age has been categorized into five age groups. Most of the respondents participated in this study were in age group from 19 to 35 . The level of education of majority of the consumers was secondary or higher. The study has been conducted on respondents with different occupations and a lion's portions of them are private service holder. Consumer's income has been classified into six categories.

Table 2: Sources from where consumer learns about green product

\begin{tabular}{|l|l|l|l|}
\hline \multicolumn{1}{|c|}{ Sources } & \multicolumn{1}{|c|}{$\begin{array}{c}\text { Percentage } \\
\text { of respondents }\end{array}$} & \multicolumn{1}{c|}{ Sources } & \multicolumn{1}{c|}{$\begin{array}{c}\text { Percentage of } \\
\text { respondents }\end{array}$} \\
\hline Advertisement & $94 \%$ & Past experience of use & $36 \%$ \\
\hline Word of Mouth & $82 \%$ & Shopkeeper's recommendation & $29 \%$ \\
\hline Peer group/colleges/friends & $69 \%$ & & \\
\hline
\end{tabular}

Table 2 reveals the sources from where consumers get to know about green products. The greater numbers of the respondents were informed of green products through advertisement and another important source that makes consumer aware about green products is word of mouth communication. $69 \%$ of the 
NCC JOURNAL - 2019

respondents become acquainted with green products from peer groups, colleague, and friends. $36 \%$ of the respondents have learned about green products from their experience and $29 \%$ of them have got recommendation from shopkeepers.

Table 3: Customers' response towards the statement, "Green products are different form conventional product"

\begin{tabular}{|c|c|}
\hline Response & Percentage of respondents \\
\hline No Yes & $10.4 \%$ \\
& $68.8 \%$ \\
Not sure & $20.8 \%$ \\
\hline Total & $100.0 \%$ \\
\hline
\end{tabular}

Table 3 shows consumers perceived differences between green products and conventional products. In totality $68 \%$ respondents were able to differentiate green products from conventional products. $20.08 \%$ had ambiguous knowledge regarding the differences and $10 \%$ of them were not able to sense anything that makes green products different from conventional products.

Table 4: Customers' response towards the statement, "Green products are different form conventional product"

\begin{tabular}{|c|c|}
\hline Response & Percentage of respondents \\
\hline No Yes & $10.4 \%$ \\
Not sure & $68.8 \%$ \\
& $20.8 \%$ \\
\hline Total & $100.0 \%$ \\
\hline
\end{tabular}

Table 4 shows consumers perceived differences between green products and conventional products. In totality $68 \%$ respondents were able to differentiate green products from conventional products. $20.08 \%$ had ambiguous knowledge regarding the differences and $10 \%$ of them were not able to sense anything that makes green products different from conventional products.

Table 5: Consumers' knowledge about various features of green product

\begin{tabular}{|l|c|c|}
\hline Features & Frequency & Percentage \\
\hline Healthy and Safe & 107 & $55.7 \%$ \\
\hline Made with natural ingredients & 73 & $38.0 \%$ \\
\hline Energy efficiency & 71 & $37.0 \%$ \\
\hline Eco friendly packaging & 60 & $31.3 \%$ \\
\hline Low hazardous emission & 43 & $22.4 \%$ \\
\hline Biodegradability & 38 & $19.8 \%$ \\
\hline Free of toxic chemical & 34 & $34.77 \%$ \\
\hline Durability Originally grown & 30 & $15.6 \%$ \\
\hline Reusable & 29 & $15.1 \%$ \\
\hline Recyclability & 29 & \\
\hline Renewable & 21 & $10.9 \%$ \\
\hline
\end{tabular}

Table 5 displays that most of the respondents' comprehended green products as healthy and safe products. $38 \%$ of the respondents viewed green products as products produced with natural ingredients, $37 \%$ considered green products as energy efficient products, and $34 \%$ conceived $\sim 50 \sim$ 
Vol. 4, No. 1

green products as toxic chemical free products. A greater number of respondents were having indistinct knowledge about the other features of green products like biodegradability, durability, originally grown, reusability, recyclability and renewability.

Table 6: Most conventionally consumed green products

\begin{tabular}{|l|c|c|}
\hline Product name & Frequency & Percentage \\
\hline Furniture & 72 & $37.5 \%$ \\
\hline Herbal medicine & 71 & $37.0 \%$ \\
\hline Electrical appliances & 61 & $31.77 \%$ \\
\hline Organic food & 56 & $29.2 \%$ \\
\hline Household cleaning products & 52 & $27.1 \%$ \\
\hline Clothing & 48 & $25.0 \%$ \\
\hline Beauty products & 46 & $24.0 \%$ \\
\hline Automobile & 7 & $3.6 \%$ \\
\hline
\end{tabular}

Table 6 represents the variety of green products purchased by the consumers. Of all types of green products listed in table 4, majority of respondents asserted that they mostly buy green furniture and herbal medicine. $31.8 \%$ of the respondents considered green products while buying electrical appliances. Organic food, green household cleaning products, green clothing and green beauty products were also given preferences while buying green products, but green automobile was the least preferable green product to the respondents.

Table 7: Consumer perceptions towards the pricing of green product

\begin{tabular}{|c|c|c|c|c|c|}
\hline & & Response & Frequency & Percentage & Average (SD) \\
\hline 1. & $\begin{array}{l}\text { Green products } \\
\text { areoverpriced }\end{array}$ & $\begin{array}{l}\text { Strongly disagree } \\
\text { Disagree } \\
\text { Neutral Agree } \\
\text { Strongly agree }\end{array}$ & $\begin{array}{l}5 \\
66 \\
67 \\
40 \\
12 \\
\end{array}$ & $\begin{array}{c}2.60 \% \\
34.4 \% \\
35.9 \% \\
20.8 \% \\
6.30 \% \\
\end{array}$ & $\begin{array}{c}2.97 \\
(0.96)\end{array}$ \\
\hline 2. & $\begin{array}{l}\text { The Maximum price } \\
\text { charged by the retailer is } \\
\text { not fixed by the producer }\end{array}$ & $\begin{array}{l}\text { Strongly disagree } \\
\text { Disagree } \\
\text { Neutral Agree } \\
\text { Strongly agree }\end{array}$ & $\begin{array}{l}10 \\
20 \\
46 \\
93 \\
22\end{array}$ & $\begin{array}{c}5.20 \% \\
10.4 \% \\
24.0 \% \\
48.4 \% \\
11.5 \%\end{array}$ & $\begin{array}{l}3.51 \\
(1.00)\end{array}$ \\
\hline
\end{tabular}

Table: 7 uncovers the consumers' perception concerning the price of green products. As disclosed from table 5, the greater number of respondents was not sure about whether green products are overpriced or not. $36 \%$ of the respondents concluded that green products are not overpriced and rests $26 \%$ think the opposite of that. Of all the respondents, $60 \%$ accepted the fact that the maximum price charged by the retailer is not fixed by the producer. 
NCC JOURNAL - 2019

Table 8: Consumer perception towards the benefits of green product

\begin{tabular}{|c|c|c|c|c|c|}
\hline & & Response & Frequency & Percentage & $0(\mathrm{SD})$ \\
\hline 1. & $\begin{array}{l}\text { Green product offers lower } \\
\text { quality compare to } \\
\text { conventional product }\end{array}$ & $\begin{array}{l}\text { Strongly disagree } \\
\text { Disagree } \\
\text { Neutral } \\
\text { Agree } \\
\text { Strongly agree }\end{array}$ & $\begin{array}{l}10 \\
37 \\
75 \\
58 \\
12\end{array}$ & $\begin{array}{l}5.2 \% \\
19.3 \% \\
39.1 \% \\
30.2 \% \\
6.3 \%\end{array}$ & $\begin{array}{l}2.34 \\
(0.89)\end{array}$ \\
\hline 2. & $\begin{array}{l}\text { Green product has no long } \\
\text { lasting positive effect }\end{array}$ & $\begin{array}{l}\text { Strongly disagree } \\
\text { Disagree } \\
\text { Neutral } \\
\text { Agree } \\
\text { Strongly agree }\end{array}$ & $\begin{array}{l}11 \\
43 \\
66 \\
55 \\
17\end{array}$ & $\begin{array}{l}5.7 \% \\
22.4 \% \\
34.4 \% \\
28.6 \% \\
8.9 \%\end{array}$ & $\begin{array}{l}3.13 \\
(1.04)\end{array}$ \\
\hline 3. & $\begin{array}{l}\text { Green products lasted long } \\
\text { time }\end{array}$ & $\begin{array}{l}\text { Strongly disagree } \\
\text { Disagree } \\
\text { Neutral } \\
\text { Agree } \\
\text { Strongly agree }\end{array}$ & $\begin{array}{l}15 \\
85 \\
63 \\
21 \\
17\end{array}$ & $\begin{array}{l}7.8 \% \\
44.3 \% \\
32.8 \% \\
10.9 \% \\
4.2 \%\end{array}$ & $\begin{array}{l}2.59 \\
(0.93\end{array}$ \\
\hline 4. & $\begin{array}{l}\text { Green products have partial } \\
\text { effect or side effect }\end{array}$ & $\begin{array}{l}\text { Strongly disagree } \\
\text { Disagree } \\
\text { Neutral } \\
\text { Agree } \\
\text { Strongly agree }\end{array}$ & $\begin{array}{l}28 \\
84 \\
62 \\
16 \\
2\end{array}$ & $\begin{array}{c}14.6 \% \\
43.8 \% \\
32.3 \% \\
8.3 \% \\
1.0 \%\end{array}$ & $\begin{array}{l}2.37 \\
(0.87)\end{array}$ \\
\hline
\end{tabular}

Table: 8 exhibits consumers' discernment regarding various attributes of green products. Consumers perception towards the quality comparison between green products and conventional products suggests that a significant part (36\%) of the consumers believed that, green products offer lower quality compare to conventional products. A larger portion of the consumers were unaware regarding this matter. The results also represent that, although majority of respondents have the knowledge about the longevity of green products, a considerable percentage (37.5\%) of them are ignorant about the long-lasting positive effects of these products. A Larger part (65.6\%) of the consumers was aware of that green products are innocuous in nature 
Table 9: Consumer opinion regarding the promotional strategies of green products

\begin{tabular}{|c|c|c|c|c|c|}
\hline & & Response & Frequency & Percentage & Average (SD) \\
\hline 1. & $\begin{array}{l}\text { The promotional messages } \\
\text { used to communicate green } \\
\text { products are not easily } \\
\text { understandable by consumer. }\end{array}$ & $\begin{array}{c}\text { Strongly disagree } \\
\text { Disagree } \\
\text { Neutral } \\
\text { Agree } \\
\text { Strongly agree } \\
\end{array}$ & $\begin{array}{c}10 \\
49 \\
55 \\
69 \\
9 \\
\end{array}$ & $\begin{array}{c}5.21 \% \\
25.5 \% \\
28.6 \% \\
35.9 \% \\
4.7 \% \\
\end{array}$ & $\begin{array}{l}3.09 \\
(1.0)\end{array}$ \\
\hline 2. & $\begin{array}{l}\text { Marketer are not adequately } \\
\text { communicate the benefits of } \\
\text { green products }\end{array}$ & $\begin{array}{c}\text { Strongly disagree } \\
\text { Disagree } \\
\text { Neutral } \\
\text { Agree } \\
\text { Strongly agree }\end{array}$ & $\begin{array}{c}5 \\
13 \\
40 \\
96 \\
38\end{array}$ & $\begin{array}{c}2.6 \% \\
6.8 \% \\
20.8 \% \\
50 \% \\
20 \% \\
\end{array}$ & $\begin{array}{c}3.89 \\
(1.43)\end{array}$ \\
\hline 3. & $\begin{array}{l}\text { Green products are not well } \\
\text { communicated and advertised } \\
\text { compare to conventional } \\
\text { products. }\end{array}$ & $\begin{array}{c}\text { Strongly disagree } \\
\text { Disagree } \\
\text { Neutral } \\
\text { Agree } \\
\text { Strongly agree }\end{array}$ & $\begin{array}{c}3 \\
7 \\
29 \\
102 \\
51 \\
\end{array}$ & $\begin{array}{l}1.6 \% \\
3.6 \% \\
15.1 \% \\
53.1 \% \\
26.6 \% \\
\end{array}$ & $\begin{array}{l}3.99 \\
(.84)\end{array}$ \\
\hline 4. & $\begin{array}{l}\text { Marketer claims regarding } \\
\text { green products are skeptical } \\
\text { and hard to believe. }\end{array}$ & $\begin{array}{c}\text { Strongly disagree } \\
\text { Disagree } \\
\text { Neutral } \\
\text { Agree } \\
\text { Strongly agree }\end{array}$ & $\begin{array}{l}4 \\
24 \\
47 \\
75 \\
40\end{array}$ & $\begin{array}{c}2.1 \% \\
12.5 \% \\
24.5 \% \\
39.1 \% \\
20.8 \%\end{array}$ & $\begin{array}{c}3.65 \\
(1.01)\end{array}$ \\
\hline
\end{tabular}

Table: 9 represents consumers' judgment based on a five-point Likert scale towards the promotional strategies of green products. The analysis revels that, majority of the respondents $(40.6 \%)$ think that, the promotional massages regarding green products, communicated by the marketers are not easily understandable by the consumer. A remarkable percentage of the consumers believe that, green products are not well communicated or advertised. They also feel that, marketer's strategies to communicate the benefits of green product with the customers are not adequate and sometimes, the claims made by them regarding these products are very skeptical and hard to believe. So, it is clear that, consumers possessed very pessimistic opinion towards the promotional strategies of green products.

Table 10: Consumer opinion about the availability of green product

\begin{tabular}{|l|c|c|}
\hline \multicolumn{1}{|c|}{ Response } & Frequency & Percentage \\
\hline Strongly disagree & 8 & $4.2 \%$ \\
Disagree & 35 & $18.2 \%$ \\
Neutral & 50 & $26.0 \%$ \\
Agree & 86 & $44.8 \%$ \\
Strongly agree & 13 & $6.8 \%$ \\
\hline
\end{tabular}


NCC JOURNAL - 2019

Table: 10 shows consumer opinion about the availability of green products when they consider buying. $50 \%$ of the respondents assumed that green products are not readily available when they want to buy and $22 \%$ of the consumers' opinion was that green products are available to buy.

Table 11: The most sought after features of green products

\begin{tabular}{|l|c|c|c|c|c|}
\hline \multicolumn{1}{|c|}{ Features } & Frequency & Percentage & Features & Frequency & Percentage \\
\hline Eco friendliness & 104 & $54.2 \%$ & Durability & 28 & $14.6 \%$ \\
\hline Safety & 80 & $41.7 \%$ & Recyclable & 18 & $9.4 \%$ \\
\hline Less polluting & 56 & $29.2 \%$ & Reusable & 16 & $8.3 \%$ \\
\hline Acceptable price & 50 & $26.0 \%$ & & & \\
\hline Long term health & 48 & $25.0 \%$ & & & \\
\hline benefit & & & & & \\
\hline Energy efficiency & 41 & $21.4 \%$ & & & \\
\hline Longer lasting effect & 35 & $18.2 \%$ & & & \\
\hline
\end{tabular}

Table 11, uncovers the findings concerning the most attractive features of green products to consumer. Majority of the respondents viewed eco- friendliness as the most attractive feature of green products followed by safety, less polluting, acceptable price, long term health benefit, energy efficiency, long lasting effects, durability, recyclability and reusability.

Table 12: Perceptual differences by Age and Education

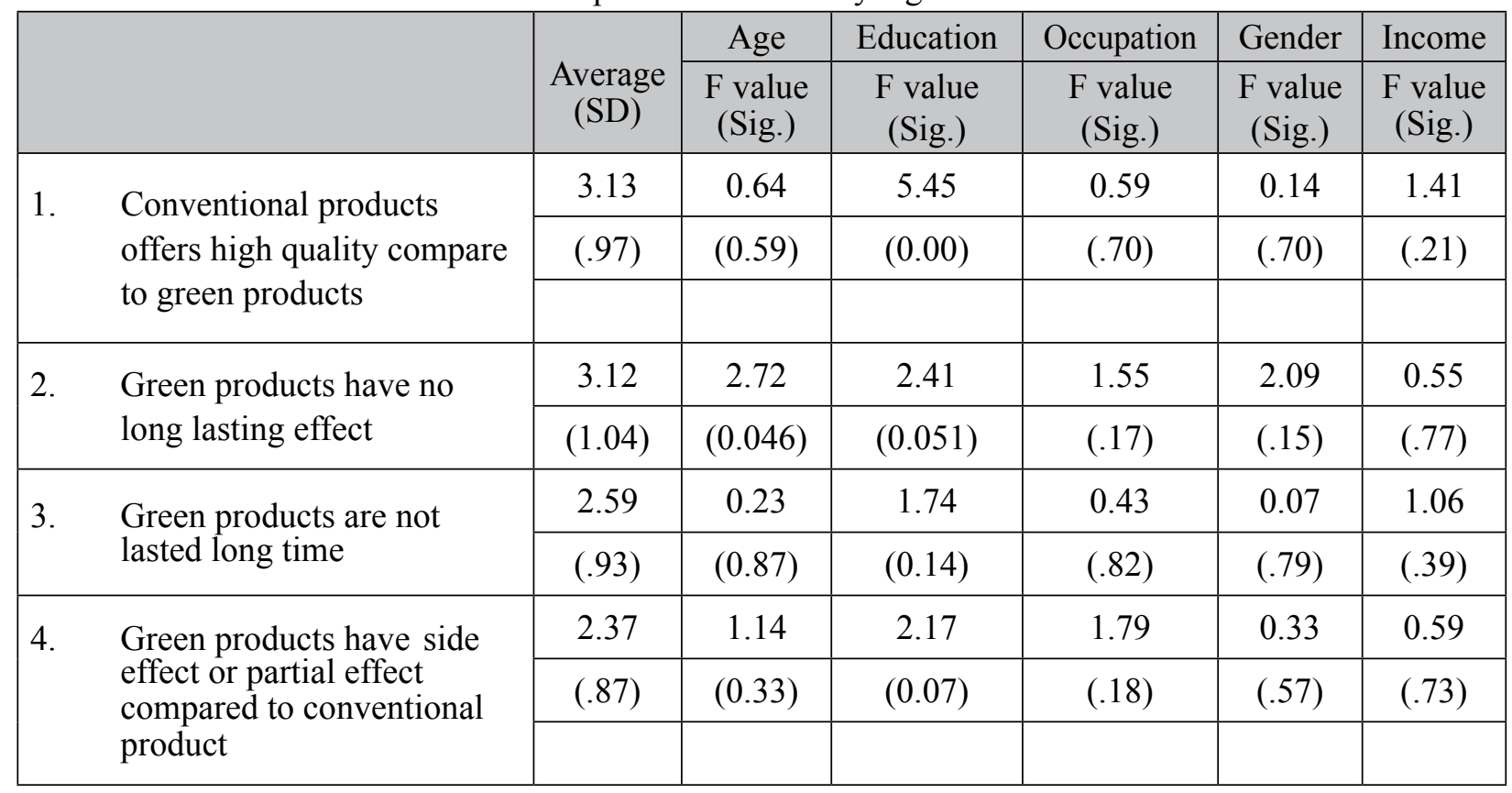

Table: 12, represents ANOVA test results across several demographic factors regarding consumer's perception towards various benefits of green product. Based on the F-test score and corresponding p-values it is found that consumer's perception differs only in terms of age and level of education. No significant difference has been found in case of other demographic factors. 


\begin{tabular}{|c|c|c|c|c|c|}
\hline & & Response & Frequency & Percentage & Average (SD) \\
\hline 1. & $\begin{array}{l}\text { I take environment consideration } \\
\text { into account while buying green } \\
\text { product }\end{array}$ & $\begin{array}{l}\text { Strongly disagree } \\
\text { Disagree } \\
\text { Neutral } \\
\text { Agree } \\
\text { Strongly agree }\end{array}$ & $\begin{array}{c}6 \\
20 \\
39 \\
73 \\
54\end{array}$ & $\begin{array}{c}3.1 \% \\
10.4 \% \\
20.3 \% \\
38.0 \% \\
28.1 \%\end{array}$ & $\begin{array}{c}3.77 \\
(2.41)\end{array}$ \\
\hline 2. & $\begin{array}{l}\text { While buying I read products label } \\
\text { to see if contents are eco friendly }\end{array}$ & $\begin{array}{l}\text { Strongly disagree } \\
\text { Disagree } \\
\text { Neutral } \\
\text { Agree } \\
\text { Strongly agree }\end{array}$ & $\begin{array}{c}4 \\
28 \\
38 \\
88 \\
34\end{array}$ & $\begin{array}{c}2.1 \% \\
14.6 \% \\
19.8 \% \\
45.8 \% \\
17.7 \%\end{array}$ & $\begin{array}{c}3.46 \\
(1.11)\end{array}$ \\
\hline & $\begin{array}{l}\text { For healthy living I will buy green } \\
\text { products if it is overpriced }\end{array}$ & $\begin{array}{l}\text { Strongly disagree } \\
\text { Disagree } \\
\text { Neutral } \\
\text { Agree } \\
\text { Strongly agree }\end{array}$ & $\begin{array}{l}10 \\
30 \\
48 \\
69 \\
35\end{array}$ & $\begin{array}{c}5.2 \% \\
15.6 \% \\
25.0 \% \\
35.9 \% \\
18.2 \% \\
\end{array}$ & $\begin{array}{c}3.77 \\
(1.06)\end{array}$ \\
\hline
\end{tabular}

Table 13 discloses that most of the consumer (66.1\%) likes to take environmental consideration intensely while buying green products. Majority of them also prefer to find out whether the product's contents are eco- friendly or not. Only $54.1 \%$ of the customers agreed that they buy these products for healthy living.

Table 14: Green product purcha ographic factors

\begin{tabular}{|c|c|c|c|c|c|c|c|}
\hline & & $\begin{array}{l}\text { Average } \\
\text { (SD) }\end{array}$ & Age & Occupation & Gender & Income & $\begin{array}{l}\text { Educa- } \\
\text { tion }\end{array}$ \\
\hline & & $\begin{array}{l}\text { F value } \\
\text { (Sig.) }\end{array}$ & $\begin{array}{l}\text { F value } \\
\text { (Sig.) }\end{array}$ & F value (Sig.) & $\begin{array}{l}\text { F value } \\
\text { (Sig.) }\end{array}$ & $\begin{array}{l}\text { F value } \\
\text { (Sig.) }\end{array}$ & \\
\hline 1. & $\begin{array}{l}\text { I take environment } \\
\text { consideration into } \\
\text { account } \\
\text { while buying green } \\
\text { product }\end{array}$ & $\begin{array}{c}3.77 \\
(1.07)\end{array}$ & $\begin{array}{l}7.84 \\
(.00)\end{array}$ & $\begin{array}{l}4.21 \\
(.00)\end{array}$ & $\begin{array}{l}2.90 \\
(.15)\end{array}$ & $\begin{array}{l}1.50 \\
(.18)\end{array}$ & $\begin{array}{l}0.80 \\
(.49)\end{array}$ \\
\hline 2. & $\begin{array}{l}\text { While buying I read } \\
\text { products label to see if } \\
\text { contents are eco } \\
\text { friendly }\end{array}$ & $\begin{array}{c}3.77 \\
(2.41)\end{array}$ & $\begin{array}{l}2.25 \\
(.06)\end{array}$ & $\begin{array}{l}3.34 \\
(.01)\end{array}$ & $\begin{array}{l}3.20 \\
(.07)\end{array}$ & $\begin{array}{r}1.00 \\
(0.42)\end{array}$ & $\begin{array}{l}0.41 \\
(.75)\end{array}$ \\
\hline 3. & $\begin{array}{l}\text { For healthy living I } \\
\text { will buy green prod- } \\
\text { ucts if it is overpriced }\end{array}$ & $\begin{array}{c}3.46 \\
(1.12)\end{array}$ & $\begin{array}{l}3.03 \\
(.02)\end{array}$ & $\begin{array}{l}5.26 \\
(.00)\end{array}$ & $\begin{array}{l}1.92 \\
(.17)\end{array}$ & $\begin{array}{l}0.75 \\
(0.61)\end{array}$ & $\begin{array}{l}1.43 \\
(.23)\end{array}$ \\
\hline
\end{tabular}

Table 14 represents the results of ANOVA F-tests score with corresponding p-values which has been performed to know whether there is any significant difference in consumer's purchase intension in terms 
of age, income, education and occupation. Observing the test score, it is found that, the purchase intension significantly varies by age and occupation of the respondent. On the other hand, Consumer's level of education and income has no significant impact on purchase intension.

\section{Conclusion}

The study has been approached with an intension to explore the consumer awareness and purchase attitude towards green products in NepaL. It can be inferred from the above study that consumer level of awareness about the differences between green products and conventional products found to be very favorable, but consumers' have superficial knowledge about various features of green products. Advertisement and word of mouth communication observed to be the leading sources from where they get to know about it. From the analysis, it is found that consumer's knowledge is not so manifest about the various benefits of green products. Significant perceptual differences have been found among the consumers with different age and level of education in this regard. The research also explores that consumers' have assorted opinion concerning the price of the green products. But it was agreed by most of the consumers' that green products are not convenient to buy. So, marketer should ensure green products obtainability to consumers. Consumers are very negative regarding the promotional strategies taken by the marketer to communicate various benefits of green product. Therefore, they are dubious about green claims. So, products positioning messages used by the marketer need to be more explicit and green claims should be more convincible. Marketer should adequately communicate the benefits of green products that provide assurance of the maximal satisfaction to consumer. It has been also found by the study that environmental safety and ecofriendly product contents are the important factors that drive consumer to buy green product. The overall analysis suggests that marketer should take initiatives in educating consumers about green products and promote in that way so that consumers become more aware about several features, benefit and price of the products and get interested to buy the products.

\section{References}

Akter, J. (2012), "Consumer Attitude towards Green Marketing in Bangladesh", ASA University Review, 6(1), 157- 166.

Ahmed, R. \& Rajendran, R. (2014). "A Study on Consumer Awareness of green products and its Impact on Green Buying Behavior", International Journal of Research, 1(8), 1483-1493.

Chang, N. \& Fong, C. (2010). "Green Product Quality, Green Corporate Image, Green Customer Satisfaction, and Green Customer Loyalty”, African Journal of Business Management, 4(13), 2836-2844.

Chen, T. B. \& Chai, L. T. (2010). "Attitude towards the Environment and Green Products: Consumers' Perspective", Management Science and Engineering, 4(2), 27-39. http://dx.doi.org/10.3968/j. mse.1913035X20100402.002 Cherian, J. \& Jacob, J. (2012). "Green Marketing: A Study of Consumers' Attitude towards Environment Friendly

Products”, Asian Social Science, 8(12), 117-126. https://doi.org/10.5539/ass.v8n12p117

Chaubey, S. \& Patra, S. (2014). "Attitude towards the Environment and Green Products: An Empirical study",

International Journal of Research in Computer Application \& Management, 1(8), 34-42.

Gan, C., Wee, H. Y., Ozanne, L. \& Kao, T. H. (2008). "Consumers' purchasing behavior towards green products in New Zealand", Innovative Marketing ,4(1), 93-102.

Gan, C., Zhiyou, M.C., Tran, D. A. Cohen \& W. Xiangxiang (2014). "Consumer attitudes toward the Purchaseof Organic Products in China”, Faculty of Agribusiness \& Commerce, Lincoln. University, Paper no. 15.

Hess, E. \& Timen, P. (2008). "Environmental Friendliness - A Marketing Strategy, Master Thesis within Business Administration", Internationella Handelshogskolan Hogskolan Jonkoping.

Kumar, S., Garg, R. \& Makkar, A. (2012). "Consumer Awareness and Perception towards Green Products: A Study of Youngsters in India”, International Journal of Marketing \& Business Communication, 1(4), 
$35-43$.

Khedkar, E. B. (2015). "Green Marketing- Concept, Awareness and Linkage with Consumer Purchase Decision",

International Journal Of Management Sciences and Business Research, 4(1), 14-18.

Maheshwari, A. \& Malhotra, G. (2011). "Green Marketing: A Study on Indian Youth”, International Journal of Management and Strategy, 2(3), 1-15.

Rayhan, A. I., Khan, A. I. \& Islam, M. T.(2014). "Factors Affecting Green Marketing in Bangladesh", Global Journal of Management and Business Research: E Marketing, 14(1), 23-40.

Saschdev, S. (2011). "Eco-friendly Products and Consumer Perception", International Journal of Multidisciplinary Research, 1(5), 1-12

Thapa G. (2008). Dictionary of Marketing. Kathmandu: Buddha Publisher and Distributor Pvt. Ltd.

Thapa G. (2019). Marketing Management. Kathmandu: Ashmita Publication 